International Research Journal of Management, IT \& Social Sciences
Available online at https://sloap.org/journals/index.php/irjmis/
Vol. 9 No. 1, January 2022, pages: 151-158
ISSN: 2395-7492
https://doi.org/10.21744/irjmis.v9n1.2018

\title{
Does Transformational Leadership, Empowerment, and Work Ethic Effect on Job Enrichment and Employee Performance?
}

Article history:

Submitted: 18 October 2021

Revised: 09 November 2021

Accepted: 27 December 2021

\section{Keywords:}

employee performance; empowerment;

job enrichment;

transformational leadership;

work ethic;

\begin{abstract}
This study aims to prove and analyze the effect of transformational leadership, empowerment, work ethic on job enrichment and employee performance. The object and location of this research is the Village Credit Institution (LPD) as a financial institution owned by Pakraman Village in 9 districts/cities in Bali. The sampling technique is based on the proportionate random sampling method, which is taking samples from each LPD area of?? The Traditional Village randomly and proportionally, because the population members are homogeneous. The size of the sample is 300 people. Based on the results of the analysis and hypothesis testing that have been carried out, the results of this study indicate that of the 7 hypotheses proposed, all of them are proven true or supported by empirical facts, which predict a significant direct effect between transformational leadership factors, empowerment, work ethic and employee performance.
\end{abstract}

International research journal of management, IT and social sciences (C) 2022. This is an open access article under the CC BY-NC-ND license (https://creativecommons.org/licenses/by-nc-nd/4.0/).

\section{Corresponding author:}

I Komang Gede,

Doctoral Program in Economics, Faculty of Economics, 17 Agustus 1945 University, Surabaya, Indonesia.

Email address: komanggede187@unhi.ac.id

\footnotetext{
Doctoral Program in Economics, Faculty of Economics, 17 Agustus 1945 University, Surabaya, Indonesia

Doctoral Program in Economics, Faculty of Economics, 17 Agustus 1945 University, Surabaya, Indonesia Doctoral Program in Economics, Faculty of Economics, 17 Agustus 1945 University, Surabaya, Indonesia
} 


\section{Introduction}

The success of company management is largely determined by the utilization of human resources, where company managers must pay attention to the attitudes, behaviors, desires and needs of employees so that employees can be encouraged to improve their performance and an organization is required to empower these people as much as possible in order to create and increase performance and commitment so that the organization can be strong and competent (Arikunto \& Jabar, 2014). Realizing a good company performance requires maximum employee performance in running the LPD, because by having performance based on good skills and abilities later can be used as role models who are able to provide input and ideas for employees to be able to further improve innovation and performance. Because in organizational change, both planned and unplanned, the most important aspect is improving performance. According to Mangkunegara \& Huddin (2016), that the term performance comes from the word job performance, namely the work that is to be achieved or achieved by individuals or groups. Employees who have high performance are more likely to speak positively about the organization, help co-workers, and make them work beyond what is formal or customary standards of a work organization, thus bringing implications for the formation of good performance. Employee performance is closely related to transformational leadership style (Febriani \& Subudi, 2014).

Hatta et al. (2018), confirmed that transformational leadership can affect employee performance. Transformational leadership is important because it can inspire employees to go beyond their personal interests and have a profound and extraordinary impact on employees. Transformational leadership is the best type of leadership because it can motivate employees to work in accordance with goals that have never been achieved before, pay attention to employees, are able to train, and make employees loyal to the company (Robbins \& Coulter, 2016). Transformational leadership is a leader who devotes his attention to the problems faced by his followers and the development needs of each of his followers by providing enthusiasm and encouragement to achieve his goals (Robbins \& Coulter, 2016). Transformational leadership is an ethical leadership style that involves the ability of a leader to promote intellectual stimulation through inspiration (Shu-Hung Hsu, 2014). According to Mukundu (2014), transformational leadership is an attitude that a leader has to build loyalty and devotion without much consideration for their own interests, and which also helps followers identify them (Pidada et al., 2021; Yunita \& Saputra, 2019).

Another factor that affects employee performance is empowerment. The importance of empowering human resources in order to improve overall company performance is known as HR management. If applied accurately and wisely, HR management is able to maximize the performance of a company so that its development can run even faster (Rajkumar \& Bhuvaneswari, 2016). Empowerment is the authority to make decisions in a certain area of operations without having to obtain approval from others (Luthans \& Youssef-Morgan, 2017). Empowerment is the granting of authority to employees to plan, control and make decisions on the work they are responsible for without having to get explicit authorization from their superiors. It is proven that the performance of employees in an agency can be improved by paying attention to the work ethic of employees. The importance of work ethic because it is beneficial for the company because if employees have a high work ethic, they will be able to increase their competence. That is, work ethic is the basic capital for someone to be able to improve their knowledge and skills. Work ethic is a reflection of a basic life attitude, so work ethic is basically also a reflection of a values-oriented view of life with a transcendent dimension (Schaltegger \& Torgler, 2010; Hayati \& Caniago, 2012).

The results show that work ethic has a significant effect on employee performance. According to Hardiansyah (2017), work ethic is a set of positive work behaviors rooted in strong cooperation, fundamental beliefs, accompanied by a total commitment to an integral work paradigm. Work ethic is a basic attitude towards self that forms positive work behavior rooted in mental awareness, fundamental beliefs, accompanied by a total commitment to an integral work paradigm. If it is associated with the situation of human life that is developing, then a high work ethic will be used as an absolute requirement, which is grown in life. Because it will open the views and attitudes to humans to value hard work and earnestly, so as to erode careless work attitudes. According to Aghaei \& Andam (2016), an employee who has a high work ethic is indicated by: (1) hard work, where employees have a work-sick nature to be able to achieve the goals they want to achieve, (2) work discipline, where employees have an attitude of respect, respect, obey and obey the applicable regulations, (3) honest, where employees carry out their work in accordance with predetermined rules, (4) responsibility, where the work done is something that must be done with diligence and sincerity, (5) diligent, the creation of personal habits of employees to maintain and improve what has been achieved, and (6) diligent means diligent, hard-hearted, and serious (Gumusluoglu \& Ilsev, 2009; Munir et al., 2010).

One of the factors that have an important role in employee performance is by doing job enrichment for employees. Job Enrichment is a job design approach that directly applies the theory of job characteristics to make jobs more interesting and increase employee motivation. Robbins, Job enrichment provides work motivation for employees by 
giving employees the opportunity to use various abilities possessed by employees, by increasing job enrichment, it will also increase employee job satisfaction. Employee job satisfaction can be increased in various ways, including by providing job enrichment to employees Paramita et al. (2016), by increasing job enrichment, it will also increase employee job satisfaction. Job satisfaction is a set of employee feelings about whether or not work is fun (Setyaningrum, 2018). Employee job satisfaction can affect employee performance which in turn can affect the performance of the company itself (Ozdevecioglu et al., 2015).

\section{Previous study and hypothesis development}

The results of Hidayat \& Kusumawati (2015), research show that transformational leadership has a significant positive relationship to job enrichment. Frans-Agustinus (2013), states that transformational leadership has a significant positive relationship to job enrichment. Ozdevecioglu et al. (2015), stated that transformational leadership has a significant positive relationship with job enrichment.

1) H1: transformational leadership has a significant effect on job enrichment

The results of the research by Gondosiswanto \& Florencia (2015), show that empowerment has a significant positive relationship with job enrichment. Frans-Agustinus (2013), states that empowerment has a significant positive relationship to job enrichment. Ozdevecioglu et al. (2015), empowerment has a significant positive relationship with job enrichment.

2) H2: empowerment has a significant effect on job enrichment

The results of the research by Gondosiswanto \& Florencia (2015), show that work ethic has a significant positive relationship with job enrichment. Hardiansyah (2017), states that work ethic has a significant positive relationship to job enrichment. Ozdevecioglu et al. (2015), work ethic has a significant positive relationship to job enrichment.

3) H3: work ethic has a significant effect on job enrichment

Fomolo (2014) transformational leadership has a positive effect on employee performance. Meanwhile, Hatta et al. (2018) reported that there was a positive relationship between transformational leadership on employee performance, and Sepdiningtyas \& Santoso (2017), stated that the results of his research on transformational leadership positively affected employee performance.

4) H4: transformational leadership has a significant effect on employee performance

Research conducted by Bakan \& Buyukbese (2013), found that there is a significant relationship between empowerment and employee performance. Rajkumar \& Bhuvaneswari (2016), states that the results of the partial correlation analysis show that empowerment is positively correlated with employee performance. Research conducted by Frans-Agustinus (2013), states that empowerment has an effect on employee performance.

5) H5: empowerment has a significant effect on employee performance

This statement is reinforced by Paramita et al. (2016), show that work ethic has a significant effect on employee performance. Frans (2015), found that work ethic has a significant and positive relationship to employee performance. Fomolo (2014), proves that there is a significant positive effect of work ethic on employee performance.

6) H6: work ethic has a significant effect on employee performance

Research conducted by Fomolo (2014), states that job enrichment has an effect on employee performance. This research is further strengthened by the research of Suparjo (2016), who said that job enrichment had a positive effect on employee performance. Research conducted by Frans-Agustinus (2013), illustrates that job enrichment has a significant positive effect on employee performance.

7) H7: job enrichment has a significant effect on employee performance.

\section{Methods}

This research was conducted in all Village Credit Institutions (LPD) in Bali Province spread across 9 districts/cities in Bali. While the scope of the research is the effect of transformational leadership, empowerment, work ethic on job enrichment, and the performance of LPD apparatus in Bali Province. The reason behind this research is that LPD in

Gede, I. K., Brahmasari, I. A., \& Ardiana, I. D. K. R. (2022). Does transformational leadership, empowerment, and work ethic effect on job enrichment and employee performance? International Research Journal of Management, IT and Social Sciences, 9(1), 151-158. https://doi.org/10.21744/irjmis.v9n1.2018 
Bali Province is a village institution engaged in financial services, must be able to provide guarantees for the quality of service to customers in supporting the smoothness and convenience of the banking service process, need to be supported by the interpersonal skills of productive and high-performance employees effectively, with the support of a leader's role in providing direction, input and motivation at work. The population in this study were all employees of the Village Credit Institution (LPD) as many as 5,178 people who answered the statements in the questionnaire regarding leadership, motivation, and employee performance. Samples that are still tolerable or desirable. The error limits that can be used are from 1-10\%. The population used in this study was 5,178 people, by used Slovin formula so the number of samples obtained was 370 respondents. The existing sample will be based on the method of proportionate random sampling. Data analysis in this study used the method of Structural Equation Modeling (SEM) analysis (Cook \& Salvendy, 1999; Griffeth, 1985).

\section{Results and Discussions}

To determine the causality relationship between each variable, a null hypothesis was tested which said that the regression coefficient between the relationships was equal to zero through the t-test in the regression model. By paying attention to the regression results in Table 5.26, it is known that the critical ratio (CR) value which is identical to the $t$ test in the regression analysis shows that all the regression coefficients are significantly not equal to zero, thus the causality relationship in the model can be accepted. The magnitude of the regression between the transformational leadership variable and job enrichment is 0.00 and the value of $\mathrm{CR}=4.391$, meaning that the transformational leadership variable has a significant effect on job enrichment. The magnitude of the regression between the transformational leadership variable and empowerment is 0.063 and the value of $\mathrm{CR}=1.859$ means that the empowerment variable has no significant effect on job enrichment. The magnitude of the regression between the work ethic and job enrichment variables is 0.04 and the $C R$ value $=2.908$, meaning that the work ethic variable has a significant effect on job enrichment (Van Dolen et al., 2004; Güngör, 2011).

The magnitude of the regression between the transformational leadership variable and OCB is 0.13 and the value of $\mathrm{CR}=2.475$, meaning that the transformational leadership variable has a significant effect on OCB. The magnitude of the regression between the empowerment variable and $\mathrm{OCB}$ is 0.00 and the value of $\mathrm{CR}=3.499$, meaning that the empowerment variable has a significant effect on OCB. The magnitude of the regression between the work ethic variable and $\mathrm{OCB}$ is 0.13 and the value of $\mathrm{CR}=2.486$, meaning that the work ethic variable has a significant effect on OCB. The magnitude of the regression between the job enrichment variable and employee performance is 0.45 and the value of $\mathrm{CR}=2.004$, meaning that the job enrichment variable has a significant effect on employee performance. The magnitude of the regression between the OCB variable and employee performance is 0.09 and the value of $\mathrm{CR}=2.611$, meaning that the transformational leadership variable has a significant effect on employee performance. The magnitude of the regression between the transformational leadership variable and employee performance is 0.061 and the value of $\mathrm{CR}=1.875$, meaning that the transformational leadership variable has no significant effect on employee performance (Scheyvens, 1999; Amichai-Hamburger et al., 2008). The magnitude of the regression between the empowerment variable and employee performance is 0.236 and the value of $\mathrm{CR}=1.184$, meaning that the transformational leadership variable has no significant effect on empowerment. The magnitude of the regression between the work ethic variable and employee performance is 0.224 and the value of $\mathrm{CR}=1.216$, meaning that the work ethic variable has no significant effect on employee performance.

Table 1

Path coefficient

\begin{tabular}{lccrrrc}
\hline & \multicolumn{2}{c}{ Regression Weight } & $\begin{array}{c}\text { Path } \\
\text { Coefficient }\end{array}$ & C.R Value & P Value & Description \\
\hline JE & $<---$ & KT &, 126 & 4,391 & 0,00 & Significant \\
JE & $<---$ & PE &, 126 & 1,859 &, 063 & Not significant \\
JE & $<---$ & EK &, 106 & 2,908 &, 004 & Significant \\
OCB & $<---$ & KT &, 099 & 2,475 &, 013 & Significant \\
OCB & $<---$ & PE &, 110 & 3,499 & 0,00 & Significant \\
OCB & $<---$ & EK &, 087 & 2,486 & 0,13 & Significant \\
\hline
\end{tabular}




\begin{tabular}{lccrrrc}
\hline & \multicolumn{1}{c}{ Regression Weight } & \multicolumn{2}{c}{$\begin{array}{c}\text { Path } \\
\text { Coefficient }\end{array}$} & C.R Value & P Value & Description \\
\hline KK & $<---$ & KT &, 141 & 1,875 & 0,061 & Not significant \\
KK & $<---$ & PE &, 137 & 1,184 & 0,236 & Not significant \\
KK & $<--$ & EK &, 115 & 1,216 &, 224 & Not significant \\
KK & $<---$ & JE &, 118 & 2,004 & 0,45 & Significant \\
KK & $<---$ & OCB &, 118 & 2,611 & 0,009 & Significant \\
\hline
\end{tabular}

Primary Data, 2021

Information:

KT : Transformational Leadership

JE : Job Enrichment

PE : Empowerment

EK : Work Ethic

OCB : Organization Citizenship Behavior (OCB)

KK : Employee Performance

Table 2

Determination coefficient

\begin{tabular}{lll}
\hline Latent & Square Multiple Correlation & \multicolumn{1}{c}{ Description } \\
\hline Job Enrichment & 0,661 & $\begin{array}{l}\text { The contribution of the effect of X1, X2, and X3 } \\
\text { together on Z1 is } 66.1 \%\end{array}$ \\
OCB & 0,402 & $\begin{array}{l}\text { The contribution of the effect of X1, X2, and X3 } \\
\text { together on Z2 is } 40.2 \% \\
\text { The contribution of the effect of X1, X2, X3, Z1 and } \\
\text { Z2 together on Y is 40.2\% }\end{array}$ \\
Employee Performance & 0,702 &
\end{tabular}

Primary Data, 2021

a. $66.1 \%$ of the variance in the job enrichment variable can be explained by the variables of transformational leadership, work ethic, and empowerment.

b. $40.2 \%$ of the variance on the OCB variable can be explained by the variables of transformational leadership, work ethic, and empowerment.

c. $70.2 \%$ of the variance in employee performance variables can be explained by the variables of transformational leadership, work ethic, and empowerment and job enrichment and organization citizenship behavior (OCB).

Base on table 1, shows in detail the relationship of direct effect, indirect effect, and total effect in this study.

1) Hypothesis 1

The magnitude of the regression between the transformational leadership variable and job enrichment is 0.00 and the value of $\mathrm{CR}=4.391$, meaning that the transformational leadership variable has a significant effect on job enrichment. This means that hypothesis 1 is accepted.

2) Hypothesis 2

The magnitude of the regression between the empowerment and job enrichment variables is 0.063 and the value of $\mathrm{CR}=1.859$ means that the empowerment variable has no significant effect on job enrichment. This means that hypothesis 2 is rejected

3) Hypothesis 3

The magnitude of the regression between the work ethic and job enrichment variables is 0.04 and the CR value $=2.908$, meaning that the work ethic variable has a significant effect on job enrichment. This means that hypothesis 3 is accepted

4) Hypothesis 4

Gede, I. K., Brahmasari, I. A., \& Ardiana, I. D. K. R. (2022). Does transformational leadership, empowerment, and work ethic effect on job enrichment and employee performance? International Research Journal of Management, IT and Social Sciences, 9(1), 151-158. https://doi.org/10.21744/irjmis.v9n1.2018 
The magnitude of the regression between the transformational leadership variable and OCB is 0.13 and the value of $\mathrm{CR}=2.475$, meaning that the transformational leadership variable has a significant effect on OCB. This means that hypothesis 4 is accepted

5) Hypothesis 5

The magnitude of the regression between the empowerment variable and OCB is 0.00 and the value of $\mathrm{CR}=$ 3.499 , meaning that the empowerment variable has a significant effect on OCB. This means that hypothesis 5 is accepted.

6) Hypothesis 6

The magnitude of the regression between the work ethic variable and OCB is 0.13 and the value of $\mathrm{CR}=$ 2.486, meaning that the work ethic variable has a significant effect on OCB. This means that hypothesis 6 is accepted

7) Hypothesis 7

The magnitude of the regression between the transformational leadership variable and employee performance is 0.061 and the value of $\mathrm{CR}=1.875$, meaning that the transformational leadership variable has no significant effect on employee performance. This means that hypothesis 7 is rejected.

8) Hypothesis 8

The magnitude of the regression between the empowerment variable and employee performance is 0.236 and the value of $\mathrm{CR}=1.184$, meaning that the transformational leadership variable has no significant effect on empowerment. This means that hypothesis 8 is rejected.

9) Hypothesis 9

The magnitude of the regression between the work ethic variable and employee performance is 0.224 and the value of $\mathrm{CR}=1.216$, meaning that the work ethic variable has no significant effect on employee performance. This means that hypothesis 9 is rejected.

10) Hypothesis 10

The magnitude of the regression between the job enrichment variable and employee performance is 0.45 and the value of $\mathrm{CR}=2.004$, meaning that the job enrichment variable has a significant effect on employee performance. This means that hypothesis 10 is accepted

11) Hypothesis 11

The magnitude of the regression between the OCB variable and employee performance is 0.09 and the value of $\mathrm{CR}=2.611$, meaning that the transformational leadership variable has a significant effect on employee performance. This means that hypothesis 11 is accepted.

\section{Conclusion}

The results of this study contribute to the development of economics, especially in the field of Human Resource Management regarding the variables of Transformational Leadership, Empowerment, Work Ethic, Job Enrichment and OCB where these variables can actually be used as a tool to improve Employee Performance at the Village Credit Institution, and this can be applied in managing the performance of employees within the Village Credit Institution in achieving superior performance efficiently and effectively, so as to encourage them to develop and meet community standards and demands. This study was conducted to examine the model on the effect of Transformational Leadership, Empowerment, Work Ethic on Job Enrichment, OCB and Employee Performance at the Village Credit Institution, and the results show that the model tested in this study is acceptable (Chitsaz-Isfahani \& Boustani, 2014). This means that the model in this study can be used. as a tool to improve employee performance at the Village Credit Institution. In addition, the results of this study can also add references in the field of Economics, especially about managing Human Resources at LPDs in the Province of Bali effectively in order to achieve performance in accordance with what is targeted.

\section{Conflict of interest statement}

The authors declared that they have no competing interests.

\section{Statement of authorship}

The authors have a responsibility for the conception and design of the study. The authors have approved the final article. 
Acknowledgments

We are grateful to two anonymous reviewers for their valuable comments on the earlier version of this paper.

\section{References}

Aghaei, A. A., \& Andam, R. (2016). The Relationship between Work Ethics and Organizational Citizenship Behaviour in Physical Education Teachers. Sport Physiology \& Management Investigations, 8(3), 53-65.

Amichai-Hamburger, Y., McKenna, K. Y., \& Tal, S. A. (2008). E-empowerment: Empowerment by the Internet. Computers in Human Behavior, 24(5), 1776-1789. https://doi.org/10.1016/j.chb.2008.02.002

Arikunto, S., \& Jabar, C. S. A. (2014). Evaluasi Program Pendidikan: pedoman teoritis praktisi pendidikan.

Bakan, I., \& Buyukbese, A. T. (2013). The relationship between employees' income level and employee job satisfaction: An empirical study. International Journal of Business and Social Science, 4(7).

Chitsaz-Isfahani, A., \& Boustani, H. R. (2014). Effects of talent management on employees retention: The mediate effect of organizational trust. International Journal of Academic Research in Economics and Management Sciences, 3(5), 114.

Cook, J. R., \& Salvendy, G. (1999). Job enrichment and mental workload in computer-based work: Implications for adaptive job design. International Journal of Industrial Ergonomics, 24(1), 13-23. https://doi.org/10.1016/S01698141(98)00084-5

Febriani, N. L. M., \& Subudi, M. (2015). Pengaruh Kepemimpinan Transformasional, Budaya Organisasi dan Kompensasi Finansial pada Kinerja Karyawan (Doctoral dissertation, Udayana University).

Fomolo, F. (2014). The impact of leader-member exchange, employee empowerment and affective commitment on TRNC hotel and restaurant workers: Implications for retention (Doctoral dissertation, Eastern Mediterranean University (EMU)-Doğu Akdeniz Üniversitesi (DAÜ)).

Frans-Agustinus, F. A. (2013). Pengaruh Leader Member Exchange Dan Pemberdayaan Melalui Mediasi Komitmen Organisasional Terhadap Kinerja (Studi Pada Kantor Notaris di Propinsi Jawa Tengah). Serat Acitya, 2(2), 134.

Gondosiswanto, C. F., \& Florencia, S. (2015). Pengaruh Job Enrichment terhadap Motivasi Kerja dan Kepuasan Kerja Karyawan Pizza Hut Surabaya. Jurnal Hospitality dan Manajemen Jasa, 3(1), 94-103.

Griffeth, R. W. (1985). Moderation of the effects of job enrichment by participation: A longitudinal field experiment. Organizational Behavior and Human Decision Processes, 35(1), 73-93. https://doi.org/10.1016/07495978(85)90045-7

Gumusluoglu, L., \& Ilsev, A. (2009). Transformational leadership, creativity, and organizational innovation. Journal of business research, 62(4), 461-473. https://doi.org/10.1016/j.jbusres.2007.07.032

Güngör, P. (2011). The relationship between reward management system and employee performance with the mediating role of motivation: A quantitative study on global banks. Procedia-Social and Behavioral Sciences, 24 , 1510-1520. https://doi.org/10.1016/j.sbspro.2011.09.029

Hardiansyah, R. O. (2017). Pengaruh Etos Kerja dan Disiplin Kerja Terhadap Kinerja Pegawai (Studi pada Pegawai Dinas Pekerjaan Umum Kota Magelang). Online tersedia di http: eprints. uny. ac. id/54151/1/RianOztaryHardiyanzah_11408144059. pdf.

Hatta, I. H., Rachbini, W., Riskarini, D., \& Mandagie, Y. R. O. (2018). OCB analysis, transformational leadership style, work ethic, work satisfaction, and good governance. Jurnal Manajemen, 22(3), 395-408.

Hayati, K., \& Caniago, I. (2012). Islamic work ethic: The role of intrinsic motivation, job satisfaction, organizational commitment and job performance. Procedia-Social and Behavioral Sciences, 65, 1102-1106. https://doi.org/10.1016/j.sbspro.2014.05.148

Hidayat, A., \& Kusumawati, R. (2015). Pengaruh Komitmen Organisasi Dan Kepuasan Kerja Terhadap Organizational Citizenship Behavior (OCB).

Luthans, F., \& Youssef-Morgan, C. M. (2017). Psychological capital: An evidence-based positive approach. Annual review of organizational psychology and organizational behavior, 4, 339-366.

Mangkunegara, A. A. A. P., \& Huddin, M. (2016). The effect of transformational leadership and job satisfaction on employee performance. Universal Journal of Management, 4(4), 189-195.

Mukundu, A. (2014). The incremental validity of cash incentive satisfaction over affective commitment, procedural justice and leadershp trust in predicting organisational citizenship behaviours.

Munir, F., Nielsen, K., \& Carneiro, I. G. (2010). Transformational leadership and depressive symptoms: A prospective study. Journal of affective disorders, 120(1-3), 235-239. https://doi.org/10.1016/j.jad.2009.03.020

Gede, I. K., Brahmasari, I. A., \& Ardiana, I. D. K. R. (2022). Does transformational leadership, empowerment, and work ethic effect on job enrichment and employee performance?. International Research Journal of Management, IT and Social Sciences, 9(1), 151-158. https://doi.org/10.21744/irjmis.v9n1.2018 
Ozdevecioglu, M., Demirtas, O., \& Kurt, T. (2015, May). The Effect of Leader-Member Exchange on Turnover Intention and Organizational Citizenship Behavior: The Mediating Role of Meaningful Work. In Proceedings of the international management conference (Vol. 9, No. 1, pp. 710-719).

Paramita, A. R., Rahardjo, M., \& Sofian, S. (2016). Analisis Faktor-faktor yang Mempengaruhi OCB Pegawai Kontrak (Studi Pada Pegawai Kontrak di Lingkungan Universitas Diponegoro Semarang). Jurnal Studi Manajemen Organisasi, 4(2), 61-69.

Pidada, I. A. I., \& Saputra, I. G. N. W. H. (2021). Examining value of employees: Effect of quality of work life, work facilities, and organizational commitments on work satisfaction. International Journal of Social Sciences and Humanities, 5(1), 57-67. https://doi.org/10.29332/ijssh.v5n1.1109

Rajkumar, P., \& Bhuvaneswari, G. (2016). Employee empowerment and employee turnover intention-An empirical analysis in life insurance sector. International Journal Business Review, 13(8), 6355-6367.

Robbins, S. P., \& Coulter, M. (2016). Manajemen, Jilid 1 Edisi 13, Alih. Bahasa: Bob Sabran Dan Devri Bardani P, Erlangga, Jakarta.

Schaltegger, C. A., \& Torgler, B. (2010). Work ethic, Protestantism, and human capital. Economics Letters, 107(2), 99-101. https://doi.org/10.1016/j.econlet.2009.12.037

Scheyvens, R. (1999). Ecotourism and the empowerment of local communities. Tourism management, 20 (2), $245-249$. https://doi.org/10.1016/S0261-5177(98)00069-7

Sepdiningtyas, R., \& Santoso, C. B. (2017). The influence of leader-member exchange on individual performance: The roles of work engagement as a mediating variable and co-workers support as a moderating variable. Review of Integrative Business and Economics Research, 6(4), 285.

Setyaningrum, R. P. (2018). The Impact of Transformational Leadership Style, Organizational Citizenship Behavior, and Work Satisfaction on A Galuh Protank Logistics Group's Employees' Performance. Wacana Journal of Social and Humanity Studies, 21(3).

Shu-Hung Hsu. (2014). "Effects of organization culture, organizational learning and IT strategy on knowledge management and performance." The Journal of International Management Studies (2014).

Suparjo, D. P. R. R. (2016). Pengaruh komitmen organisasi, kepuasan kerja dan budaya organisasi terhadap organizational citizenship behavior (OCB)(Studi Pada PT. Plasa Simpanglima Semarang). Jurnal Ilmiah Dinamika Ekonomi dan Bisnis, 1(1).

Van Dolen, W., De Ruyter, K., \& Lemmink, J. (2004). An empirical assessment of the influence of customer emotions and contact employee performance on encounter and relationship satisfaction. Journal of Business research, 57(4), 437-444. https://doi.org/10.1016/S0148-2963(02)00277-1

Yunita, P. I., \& Saputra, I. G. N. W. H. (2019). Millennial generation in accepting mutations: Impact on work stress and employee performance. International Journal of Social Sciences and Humanities, 3(1), $102-114$. https://doi.org/10.29332/ijssh.v3n1.268 